\title{
O CORPO E O SOM \\ A PERFORMANCE EM ADRIANA CALCANHOTTO
}

Daniela Aragão é doutora em Literatura Brasileira pela PUC-RIO.

Email: danielaaragao75@hotmail.com

\section{Resumo}

Este artigo propõe analisar como se processa a performance corporal na produção musical da cantora e compositora Adriana Calcanhotto. Tomando como base as reflexões de Paul Zumthor, será feito um percurso por trabalhos da artista que elucidam o desvelar de uma poética do corpo e seus desdobramentos, que coadunam num diálogo rico em referenciais que incorporam uma diversidade de elementos como som, imagem e movimento.

\section{Abstract}

This article considers to analyse how process the body performance in the musical production of the Singer Adriana Calcanhotto. On the basis of reflexion from Paul Zumthor, we will make a course around the works from this artist that shows the development of a poetic of the body and their deployments that arrives on a rich dialogue full of references that comprises a diversity of sound, image and movement.

Drummond, nos últimos versos de "Mãos dadas", define: "O tempo é a minha matéria, o tempo presente, os homens presentes, a vida presente" (ANDRADE:1978). Ao refletirmos sobre a criação da compositora e cantora Adriana Calcanhotto, inevitavelmente, mesmo que nas entrelinhas, estamos questionando sua existência no universo contemporâneo, ou seja, tudo o que envolve a produção desta artista está ligada ao tempo em que vive. Contemporânea, iconoclasta, clássica, saudosista, antenada, uma série de adjetivos serão por nós utilizados ao longo deste estudo para tentar apreender seu mundo criativo. Artista de seu tempo, Calcanhotto produz suas obras com os olhos no presente, mas consciente da força da tradição que estrutura os pilares de sua criação, que traz na contínua revisão do passado matéria prima/viva em pleno movimento de expansão, revisão e deglutição. TS Eliot no ensaio "Tradição e talento individual", elabora uma longa reflexão sobre a importância da consciência da tradição na obra de um artista. Conforme argumenta o escritor, o verdadeiro criador é aquele que sabe da importância que traz o legado de seus antepassados sobre sua criação. $\mathrm{Na}$ acepção de Eliot, a tradição não advém de uma herança adquirida por um processo natural, mas é resultado de uma conquista que requer esforço. Embora sua análise se dirija primordialmente ao universo literário, em que ele expõe os pressupostos àqueles que desejam enveredar seriamente pelo ofício da criação literária, há uma amplitude reflexiva que se expande para a criação de qualquer espécie.

Há que se refletir que a criação de um artista não se ergue sobre o primado de uma existência solitária, isolada. Passado e presente se alternam na confluência de experiências adquiridas e transformadas em objeto criativo por parte do criador. Conforme argumenta Eliot:

Nenhum poeta, nenhum artista, tem sua significação completa sozinho. Seu significado e a apreciação que dele fazemos constituem a apreciação de sua relação com os poetas e artistas mortos. Não se pode estimá-lo em si, é preciso situá-lo, para contraste e comparação, entre os mortos. Entendo isso como um princípio de estética, não apenas 
histórica, mas no sentido crítico. É necessário que ele seja harmônico, coeso e não unilateral; o que acontece quando uma nova obra de arte aparece é, às vezes, o que ocorre simultaneamente com relação a todas as obras que a precedem. (ELIOT, 1989, p.32)

Como argumenta Eliot, um artista jamais poderá existir absolutamente isolado; sua obra se compõe por seu caráter individual acrescido de uma carga de informações e influências advindas da geração em que nasceu e vive, além das outras que the antecedem. Pensar a criação de Calcanhotto implica tentar de alguma forma situá-la em relação ao seu tempo, entender de que maneira sua performance, que abrange voz, corpo, palavras, sons e imagens está se comunicando com o universo em que vive, ou seja, a contemporaneidade. Agambem, em $O$ que é o contemporâneo (2009), discute a questão da problemática que consiste na aceitação, reconhecimento e inserção do artista na atualidade. A seu ver, ser um artista contemporâneo não implica simplesmente estar inteiramente adequado às proposições e tendências de seu próprio tempo, mas estar na verdade padecendo de alguma espécie de inadequação que o faz de certa forma relativamente distanciado do tempo em que vive. $\mathrm{O}$ artista que apresenta dificuldade em se enquadrar em seu tempo de existência, deixando aflorar em si um sentimento de permanente descontinuidade, atua como uma espécie de criador aguçadamente crítico, haja vista que, não se sentindo inteiramente adaptado ao momento em que vive, apresenta uma percepção mais ampla que abrange não somente aspectos positivos (AGAMBEM, 2009, p.59).

Agamben não faz a defesa de um artista nostálgico que só encontra afinidade com o tempo passado e valores cristalizados, mas põe em questão a relação deste com seu próprio tempo. Conforme elucida o crítico, a contemporaneidade consiste numa relação singular com o próprio tempo que comporta simultaneamente adesão e distanciamento. Sendo assim, o artista que coincide muito plenamente com sua época, que a ela adere em todos os aspectos sem objeção, não é de fato um contemporâneo, pois não consegue vê-la de fato. Contemporâneo é aquele que mantém o olhar fixo no seu tempo, para nele perceber não somente as luzes, mas o escuro. Essa percepção do escuro se efetua numa perspectiva relativista que equivale a "neutralizar as luzes que provêm da época para descobrir suas trevas, o seu escuro especial, que não é, no entanto, separável daquelas luzes" (AGAMBEM, 2009, p.63). O crítico defende que o contemporâneo acima de tudo é aquele indivíduo criador que enxerga o escuro de seu tempo e não cessa de interpretá-lo a todo momento, sendo assim mais instigado por essa obscuridade que avista do que pelas luzes que em muitos aspectos recobrem mais a superfície. Sob a reflexão Agambiana ser contemporâneo implica:

Perceber no escuro do presente essa luz que procura nos alcançar e não pode fazê-lo, isso significa ser contemporâneo. Por isso os contemporâneos são raros. E por isso ser contemporâneo é, antes de tudo, uma questão de coragem: porque significa ser capaz de manter fixo o olhar no escuro da época, mas também de perceber nesse escuro uma luz que, dirigida para nós, distancia-se infinitivamente de nós. Ou ainda: ser pontual num compromisso ao qual se pode apenas faltar. (AGAMBEM, 2009, p.65) 
Ao refletirmos sobre a criação de Calcanhotto, tocam-nos algumas questões que observamos em sua produção. Pensar a linguagem criativa desta artista e suas formas de expressão coloca-nos irremediavelmente diante de algumas indagações : o que propõe a artista Adriana Calcanhotto? O que faz dela uma artista contemporânea?

Calcanhotto é uma cantora que não se ocupa estritamente com o ato de compor e cantar, visto que apresenta em suas obras contínuos diálogos com outras artes em que se sobressaem a literatura e as artes plásticas. Por meio de elaborações dialógicas constantes, ela faz sua arte se destacar no universo contemporâneo pelo tratamento apurado que constrói, no qual o aspecto performático é um dos dados mais relevantes. A palavra performance tem sido muito utilizada para designar uma diversidade de produções que povoam o universo atual e por isso mesmo sugere uma série de direcionamentos que nem sempre se encontram num mesmo seguimento, ou linha de abordagem. Em seu caráter abrangente, a performance se refere a um ato pelo qual se dá forma a alguma coisa ou se revela a forma de alguma coisa. Ela pode significar execução, desempenho, preenchimento, realização, atuação, acompanhamento, ação, ato, explosão, capacidade ou habilidade, uma cerimônia, um rito, um espetáculo, a execução de uma peça de música, uma representação teatral ou um feito acrobático.

O termo performance é bastante utilizado na arte contemporânea para designar vários tipos de intervenções artísticas nas quais o artista assume um papel ativo frente ao público, atuando muitas vezes como o próprio veículo de expressão de sua obra. Todavia a performance envolve uma consciência da duplicidade, através da qual a execução de um ato é colocada em comparação com um modelo - potencial, ideal ou relembrado - dessa ação. Em geral essa ação é realizada pelo observador da ação - o público do teatro, o professor da escola, o palestrante. O mais importante é a dupla consciência que se dá na performance : uma performance é sempre destinada a alguém, um público que reconhece e valida como performance.

O objetivo da performance é transformar o corpo em um signo, em um veículo significante, cuja unidade de trabalho se apresenta numa variedade de sentidos, sejam eles visuais, olfativos, tácteis, auditivos. O corpo é uma unidade autosuficiente e na arte da performance essa unidade é realizada como um instrumento de comunicação. $\mathrm{O}$ elemento erótico, mola propulsora de uma parcela significativa da expressividade corporal, torna indispensável por parte do performer uma consciência de si próprio para que esteja sempre apto a conduzir seus movimentos. Antes de tudo a performance é uma expressão cênica, cujo início se dá marcadamente no século XX e com o advento da modernidade. É um movimento artístico que aproxima arte e vida, resgata uma prática radical e dá vazão a uma criatividade que transmuta os elementos de expressividade. Segundo Cohen (2007), a performance se situa no limite das artes plásticas e das artes cênicas, é uma linguagem híbrida e fronteiriça que guarda características da primeira enquanto origem e da segunda enquanto finalidade. É essencialmente uma arte de intervenção, modificadora, visando causar uma transformação no público. A performance incorpora a idéia da interdisciplinariedade como caminho para uma arte total que faz uso de várias linguagens, a música se integra com a dança, ambas são 
suportadas por um cenário, uma iluminação, uma filmagem, uma plástica que se compõem num espetáculo total num lastro, que vai de espetáculos de grande espontaneidade e liberdade de execução até espetáculos altamente formalizados e deliberados.

Cohen, em sua obra Performance como Linguagem, um dos primeiros livros escritos sobre o tema no Brasil, explora relações nos âmbitos formal e ideológico da performance, desde os processos de criação às formas de entendimento da cena e suas características como arte de contestação que, assim como o happenning, apoia-se no instante do acontecimento . O autor acentua sua percepção da performance como um acontecimento imbuído de característica ritualística, ou seja, com a valorização do tempo presente e o estabelecimento de uma comunhão com o público para a condição de testemunha do acontecimento. Cohen transcende as tradicionais noções de arte como estética contemplativa, que costuma suplantar a existência de um processo interativo entre obra e espectador. Para a performance, ritualizar implica envolver, tomar o outro como parte de um processo intersubjetivo, compartilhado, coletivo (COHEN, 1997, p.56)

Cohen caracteriza a performance como um amplo campo de experimentação e pesquisa de linguagens, que incorpora elementos de várias artes. $\mathrm{O}$ artista a seu ver é uma espécie de livre "colador", que se utiliza da associação anárquica, irrestrita e libertária na criação através da mixagem, sem querer saber quais os processos hierárquicos que podem limitar sua escolha. Sendo assim, o artista sob o olhar de Cohen não se submete às imposições midiáticas ou a qualquer expectativa construída pelo próprio público, e sua liberdade aproxima-o de certa postura anárquica.

Nenhuma performance pode ser vista isolada de seu contexto, pois qualquer manifestação guarda forte associação com seu meio cultural. A vida é elemento de criação e recriação da performance, que em sua essência está imbuída de críticas relacionadas a acontecimentos da existência. Ao tocar de forma sutil ou até mesmo grotesca nos fatos da vida, os performers colocam em evidência muitas vezes a natureza estereotipada de nossos hábitos e ações.

O corpo consiste num elemento indispensável e fundamental na execução da performance, ele fornece as ferramentas de percepção e interação com o ambiente em que o artista dá vazão à extensão de sua expressividade. Principalmente quando tratamos da performance de um cantor, devemos levar em conta que seu desempenho não se limita apenas ao aparelho fonador diretamente responsável pela emissão da voz; todo o seu corpo é um campo vibratório em constante mutação. $\mathrm{O}$ corpo expressa a ambiguidade do indivíduo, tanto como sensibilidade subjetiva que experimenta o mundo, quanto como objeto percebido pelo mundo. Devido ao fato de ser uma subjetividade irradiadora que constitui o centro de toda experiência, ele não pode ser entendido adequadamente como mero objeto; mesmo assim ele funciona também na experiência do ser como objeto de consciência, inclusive de sua consciência corporificada. 
Somente nas últimas décadas do século XX o corpo se tornou de fato objeto de discussão nas Ciências Humanas, nos Estudos Culturais e na Filosofia. Ao refletirmos sobre a performance de uma cantora como Calcanhotto, estamos tentando compreender como se dá em diferentes formas e contextos o desempenho de seu corpo. A expressividade de seu canto que se compactua com o movimento de todo o corpo elucida uma arte em constante autoquestionamento e transformação. $O$ corpo é o veículo de recepção e projeção no mundo e carrega em si as memórias e histórias do indivíduo:

\begin{abstract}
Meu corpo é a materialização daquilo que me é próprio, realidade vivida e que determina minha relação com o mundo. Dotado de uma significação incomparável, ele existe à imagem de meu ser: é ele que eu vivo, possuo e sou, para o melhor e para o pior. Conjunto de tecidos e de órgãos, suporte da vida psíquica, sofrendo também as pressões do social, do institucional, do jurídico, os quais, sem dúvida, pervertem nele seu impulso primeiro. Eu me esforço, menos para apreendê-lo do que para escutá-lo, no nível do texto, da percepção cotidiana, ao som dos seus apetites, de suas penas e alegrias: contração e descontração dos músculos; tensões e relaxamentos internos, sensações de vazio, de pleno, de turgescência, mas também um ardor ou sua queda, o sentimento de uma ameaça ou, ao contrário, de segurança íntima, abertura ou dobra afetiva, opacidade ou transparência, alegria ou pena provindas de uma difusa representação de si próprio. (ZUMTHOR, 1993, p. 23, 24)
\end{abstract}

Zumthor através de suas reflexões elucida sobre o quanto o corpo de um indivíduo se projeta como reflexo-resultado de suas relações com o mundo. O mundo se materializa no corpo e, sendo assim, não existe mundo fora de uma estrutura corpórea. É no embate entre seu corpo e o universo de vidas que o circundam que o indivíduo vivencia e exterioriza suas emoções e as torna reais. O corpo é simultaneamente suporte e veículo para a criação do artista, que se dá através do acionamento dos diversos movimentos compostos por gestos, sons e palavras.

Zumthor problematiza a relação entre corpo e discurso visto que trata da utilização do corpo como meio de expressão artística. $O$ teórico aproxima a arte do caminho das necessidades humanas básicas ao retomar práticas anteriores à enunciação da voz, como o gesto. Seguindo suas prerrogativas, podemos afirmar que o gesto nasce antes da voz, pois, partindo do princípio de que os povos primitivos se comunicavam por meio de grunhidos, eles concentravam nas formas gestuais informações que não eram reproduzidas pela fala. Deve-se considerar também que toda voz emana de um corpo e existe um elo muito forte que o liga ao gesto. Assim como a voz, o gesto também projeta o corpo no espaço da performance, no instante da representação. $\mathrm{O}$ gesto e a voz se co-relacionam e a fronteira que separa esses dois campos semióticos é muito tênue, pois, conforme Zumthor "uma atitude corporal encontra seu equivalente numa inflexão da voz, e vice-versa" (ZUMTHOR: 1993, p.244). O gesto acrescido à voz permite uma ampliação do espaço de sentido que se faz por um jogo rico de significações.

O corpo se estrutura-desestrutura entre fissuras que unem e desunem múltiplos fragmentos que compõem a sua memória. Os movimentos corporais podem trazer à tona 
o desejo de materializar uma gramática orgânica, esta que segundo Zumthor agrega a memória do corpo, à medida que carrega em suas entranhas uma lembrança do mundo:

[...] a existência de uma lembrança orgânica das sensações, dos movimentos internos do corpo, ritmo do sangue, das vísceras, toda essa vida impressa de uma maneira indelével em minha consciência penumbral daquilo que sou, marca de um ser a cada instante desaparecido, e, no entanto, sempre eu mesmo (ZUMTHOR, 1993, p.79).

Como afirma Zumthor, o corpo traz em si suas memórias que se depositam em cada pedaço de seu todo. Contudo, a fixação de reminiscências não faz dele exclusivamente um mero depositário passivo de vivências e sensações. O performer responsável pela condução da expressividade de seu corpo deverá se manter disponível para explorar continuamente novas possibilidades, transformar em criação artística sua riqueza imaginativa. O corpo do artista não se sobressai numa existência isolada, dissociada dos demais seres que com ele interagem, ou seja, ele se cria e recria na comunicação que estabelece entre seu espaço interno e as forças expressivas de um outro corpo. É pela expressão atribuída por outrem que o ato performático ganha significado, dado que o corpo aparece e é visto pelo espectador.

A performance é vista, sentida e vivenciada pelo outro que a acompanha no tempo e no espaço, mesmo que a encontre na passagem, num espaço ínfimo de tempo. A performance deixa marcas, às vezes sutis, às vezes graves naqueles que por ela são tocados. O espectador que vivencia a performance pode sublimar, transformar ou esquecer a marca que tentaram lhe imprimir. Pode-se chamar de marca os estados inéditos que se produzem no corpo de um indivíduo, a partir das composições que ele vai vivendo no decorrer de sua existência. Cada um destes estados constitui uma diferença que instaura uma abertura para a criação de um novo corpo, o que significa que as marcas são sempre gênese de um devir. Principalmente o corpo do artista está sempre em devir, pois a cada novo trabalho, a cada nova apresentação diante do público ele está experimentando diferentes maneiras de se expressar. Numa performance o criador não almeja a busca de uma única forma, ele se presentifica visando compor uma intensidade de formas que marcam seu caráter transitório e instável. O caráter indefinido e impreciso da performance defendido na obra de Cohen é reiterado pelas reflexões do performer e pesquisador Lucio Agra, que celebra também sua indefinição. Segundo Agra, a performance permite novos entendimentos a cada vez que alguém se apodera dela, tornando-a uma construção em incessante devir.

[...] O caráter de expansão da linguagem, sobretudo atualmente; a sua "natural" resistência à apreensão cognitiva racionalista, a sua amplificação geográfica, a sua reverberação em vários contextos (ela mesma sendo um), sua congenialidade a outras formas emergentes de invenção artística que resultam de misturas e apropriações de formas tradicionais ou sucatas culturais, a sua predileção pelo evento efêmero, precário, dificilmente apreensível, a sua resistência às clássicas ordens identitárias, o seu caráter de proximidade ao subalterno, sua expansão em lugares antes ignotos, sua formulação em uma temporalidade espiralada (sem a teleológica perspectiva de um progresso linearascendente), a amplitude de seu campo de pesquisa, sua ilógica, sua predileção pelo 
paradoxo, o experimental. Por que deveríamos abrir mão desta conquista que é dispormos de um modo de dizer/fazer/pensar em arte que resiste às definições? Vamos adiante afirmando a dúvida. (AGRA, 2009/2010, p.6,7)

Agra define a performance como espaço de entrecruzamento de linhagens artísticas, espaço de dúvida, instabilidade e abertura para diversas possibilidades. Poderíamos inferir que a performance se situa numa espécie de encruzilhada, lugar em que o artista experimenta contínuas e dicotômicas possibilidades, um ritual que envolve ousadia e risco. $\mathrm{O}$ artista-performer por meio de sua criação amplifica as dimensões de sentido, que se constroem por um rico universo de elementos de ordens até aparentemente díspares, mas que se fundem gerando um resultado muitas vezes provocador. O corpo é sempre uma realidade experimental possível e viva, e sua "incompletude" é justamente seu passaporte para um caminho infinito de inventividades. Como dissemos, o corpo na performance não se move objetivando o alcance de uma única forma; ele se presentifica para compor uma intensidade de formas. Mesmo assim, subjaz uma organização estética à intensidade de qualquer performance, sendo esta uma composição de ação que se organiza em meio ao seu caráter provisório e instável. Zumthor problematiza a questão, enfatizando a instabilidade que percorre a denominação do próprio conceito de performance, devido ao fato de esta ser marcada justamente por sua natureza múltipla e de difícil apreensão.

A performance traz em sua essência a marca de um contínuo experimentalismo que desponta em seu caráter de permanente reconstrução. A performance transcende prerrogativas cerceadoras ao proclamar sua forma em constante re-forma, como explicita Zumthor:

Entre o sufixo determinando uma ação em curso, mas que jamais será dada por acabada, e o prefixo globalizante, que remete a uma totalidade inacessível, se não existente, performance coloca a "forma", improvável. Palavra admirável por sua riqueza e aplicação, porque ela refere menos a uma completude do que a um desejo de realização. Mas este não permanece único. A globalidade, provisória. Cada performance nova coloca tudo em causa. A forma se percebe em performance, mas a cada performance ela se transmuda. (ZUMTHOR, 1993, p.33)

Na performance, o material a ser trabalhado e permanentemente transmudado é o próprio corpo do artista e sua evolução se efetua na presença e relação com outros corpos (pessoas e objetos), além do espaço e do tempo. No ato performático o artista se torna outros sem deixar de ser o que é, ou seja, sem perder sua substância que o torna único. O performer sabe que se encontra diante de um outro, um outro de si e um outro do espaço e através desta percepção elabora suas criações. Ele se deixa atravessarperpassar por um estado de exposição criativa de si próprio, mesmo como estado transitivo possível de proporcionar a abertura para o encontro, para a alteridade.

Refletindo sobre as bases que fundamentam a conceituação de performance, constatamos o quanto o início de carreira de Calcanhotto é marcado por uma acentuada tendência performática. Para a fundamentação de nossa análise, recorremos a alguns registros áudio visuais extraídos do período em que ela ainda se apresentava em 
pequenas casas de espetáculo e era considerada uma espécie de artista "cult" pela pequena e grande imprensa que já começava a desvendá-la. Essa acepção "cult" advinha do fato de que Calcanhotto começou a despontar no cenário nacional com uma proposta musical meio dissonante em relação ao que se presentificava no final da década de oitenta. É fato que ela surge no momento em que floresciam as chamadas cantoras "ecléticas", ou seja, intérpretes que cantavam um repertório pontuado pela indefinição de gêneros. Marisa Monte, que apareceu no mesmo período, lançou seu primeiro disco com uma miscelânea de canções que iam de Kurt Weill a Candeia, Erasmo Carlos e Tim Maia. Esta artista impressionou a mídia e o público por sua versatilidade; com afinação e segurança transitava entre um repertório vasto e não buscava a princípio ser firmada sob nenhum rótulo que a carimbasse como representante de um gênero específico.

Calcanhotto, assim como Marisa Monte, se fez notar também pela escolha de um repertório pleno de mesclas, e além disso pela maneira como relia composições de gêneros diversos a seu modo. Esta artista não simplesmente mostrava a opção por um leque de canções de gêneros distintos, mas apresentava um desempenho cênico difícil de classificar. Seria uma sucessora de Nara Leão, com seu modo minimalista de acompanhar-se ao violão? Seria uma sucessora de Elis Regina, pela maneira como utilizava a voz, brincando com seus amplos recursos? Seria herdeira de uma tradição musical mais performática, a exemplo de Eduardo Dusek e Cida Moreira?

Assim que aportou no Rio de Janeiro, a cantora gaúcha apresentava um repertório de feição híbrida, que percorria a tradição das marchinhas e sambas canções (Bandeira Branca, Nunca) aliado a músicas que dialogavam com uma estética mais contemporânea, a exemplo do rock (Rádio Blá). A presença de certos elementos kitsch na escolha de algumas composições do repertório da Jovem Guarda (Namoradinha de um amigo meu), acrescidos por sua própria interpretação, também soava de certa maneira intencionalmente dissonante.

Como exemplo de desempenho acentuadamente performático, destacamos um show de Calcanhotto realizado no Teatro Rival-Rio, sob a direção do cineasta Zelito Viana. Com cerca de uma hora e meia de duração, o espetáculo, que obteve uma restrita divulgação na mídia apenas em material VHS, consiste num registro fundamental que expõe o processo de transformação pelo qual a artista passa ao longo de duas décadas de atividade. Apenas voz e violão tomam conta de uma plateia pequena, mas efusiva, que interage a todo tempo com a artista, principalmente nos momentos em que é explicitamente convidada a participar. O figurino composto por blazer, calça verde limão e blusa amarela alude às cores da bandeira nacional e compactua com um repertório que passa por clássicos de Lupicínio Rodrigues, Max Nunes e Laércio Alves, Gilson de Souza, Luiz Peixoto e Vicente Paiva, entre outros. O visual da cantora, em relação ao de hoje, é quase irreconhecível: cabelos cortados em estilo chanel com as pontas para fora e tingidos de um louro claríssimo ao estilo Marylin Monroe, compõem um caráter meio exótico, que tem seu reforço numa maquiagem forte que marca os lábios muito vermelhos em contraste com a pele alva. Mesmo levando-se em conta que 
a imagem data de mais de duas décadas, a aparência da artista neste vídeo mostra uma intenção acentuadamente provocativa.
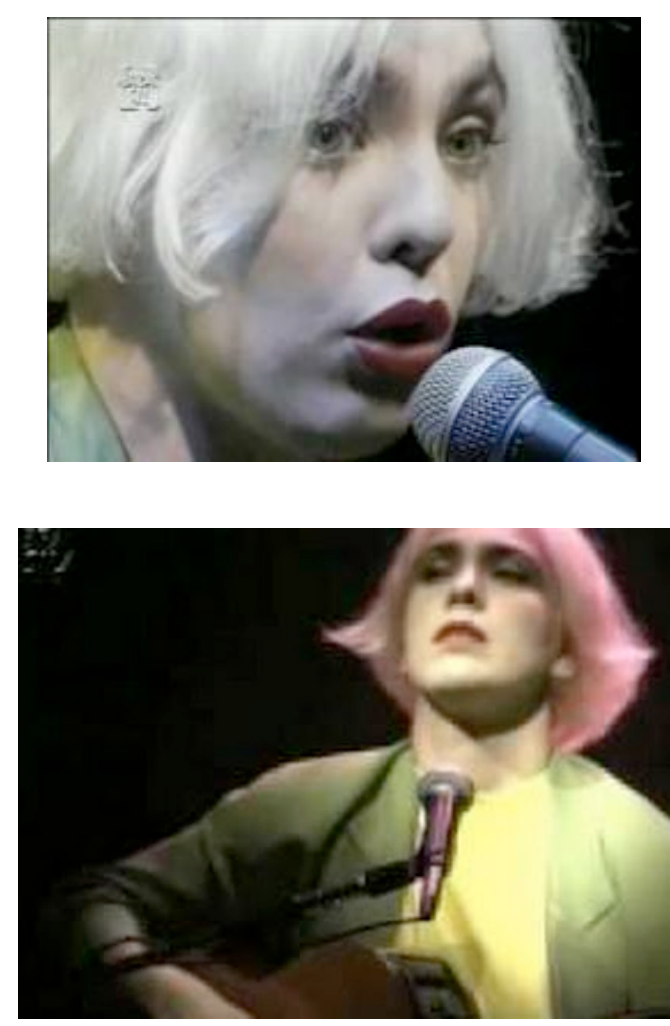

Não há nenhum artefato elaborado para o cenário: no centro do palco com fundo negro, apenas Calcanhotto acompanhada por seu violão. Nota-se que as luzes e os enquadramentos simples e quase de feição doméstica não intentam mostrar nenhuma sofisticação tecnológica que suprima a performance da artista. $\mathrm{O}$ foco cinematográfico ora incide sobre detalhes de sua expressão facial, ora capta a expressividade inteira de seu corpo. O show é apresentado do princípio ao fim com banquinho e violão, e, no entremear de algumas interpretações, são exibidos ao espectador do vídeo alguns registros de um outro show realizado por ela numa outra temporada, possivelmente anterior ao show "Enguiço", pois o cenário e figurino se distinguem.

A performance de Calcanhotto exibida no vídeo dirigido por Zelito Viana revela a desenvoltura da artista, que dá primazia a um toque de humor que envolve grande parte das interpretações. O formato voz e violão dialoga com a estética cool da Bossa Nova, contudo a expressividade corporal da cantora alterna momentos mais contidos e expansivos. A câmera se aproxima em close muitas vezes mostrando detalhes do rosto da cantora, principalmente os lábios, que respondem diretamente pela emissão da voz. $\mathrm{Na}$ interpretação da música "Injuriado" Calcanhotto constrói uma performance expressionista repleta de ironia, brincando com a letra da canção de Eduardo Dusek, que fala sobre um alguém vítima do excesso de droga. $\mathrm{O}$ tom que prima pela coloquialidade expressiva pode ser notado pela evolução dos versos: 
Não é que eu tava numa mais ou menos

Andando com a rapaziada catita e legal

Mas de repente detalhes pequenos

Me fizeram entre outras coisas sair do normal

$\mathrm{Eu}$ fui ficando pouco a pouco injuriado

Mal humorado, abandonado sem até poder amar

A tal da crise deixou minha vida maluca

Com vontade na Tijuca de voltar lá pra Copacabana

Fui à macumba

Pedi baixa no emprego

Me internaram numa clínica

Depois fui viajar

Quando voltei foi então que pude constatar

Que não adianta fazer nada

Pra essa coisa melhorar

E então melhorei! (In: CALCANHOTTO, 1990)

Ela canta várias vezes os versos da canção do começo ao fim, a cada retorno ao primeiro verso explicita-se uma mudança em sua performance vocal. A levada do violão vai adquirindo um ritmo cada vez mais acelerado e sincopado na proporção da mudança do entoar da voz de Calcanhotto, que imita a voz masculina e satiriza os movimentos faciais cada vez mais "travados" do usuário descontrolado de cocaína. Toda a performance de "Injuriado" é realizada com muito humor e descontração, levando à recepção calorosa do público. O show, registrado por Zelito Viana, contém grande parte das canções divulgadas em "Enguiço", álbum de estreia da cantora, além de outras que já vinham sendo continuamente interpretadas por ela ao longo de suas apresentações nas pequenas casas de shows. "Namoradinha de um amigo meu" (Roberto Carlos/Erasmo Carlos) recebe uma leitura singular da cantora: seu violão que se firma com batidas fortes conduz uma base sonora pulsante para a expressividade de seu canto cheio de interferências cômicas. Nos últimos versos ela brinca com as palavras "e por que não com ela", transformando-a em "e porque não comê-la", insinuando uma proposta de cunho mais erótico. Há uma faceta lúdica que floresce com revestimentos de humor nas canções em que ela intenciona mostrar uma leitura mais provocativa: Namoradinha de um amigo meu coloca em evidência uma canção do repertório da Jovem Guarda, refeita numa concepção que destaca a brincadeira, num sentido quase paródico.

O espetáculo todo se sustenta pelo primado do banquinho e violão, o que remete ao estilo tradicionalmente difundido pelos intérpretes da Bossa Nova. No entanto, o desenvolvimento corporal de Calcanhotto é consideravelmente mais expansivo do que caracteriza a expressividade do gênero. Em Sem compromisso, ela explicita uma notável movimentação que vai além da contenção cool bossanovista: mesmo assentada e abraçada ao violão, a artista reproduz o movimento da dança sugerido nos versos da canção ao mover as pernas num ritmo musical. Essa sua expressividade que se dá tanto no desempenho do corpo, como em suas expressões faciais, dão ao número uma dimensão performática que enfatiza a sua relação com o público, visando a uma permanente interatividade. Conforme argumenta Zumthor, a performance é ato de presença no mundo e em si mesma. Nela o mundo está presente. Sendo assim, não é 
possível falar da performance de um artista de maneira unívoca, sem situá-lo com o momento e ambiente em que vive. A experiência corpórea da cantora revela seus diálogos com o mundo e com o universo das artes; em cada performance executada por ela emerge um novo ser, tanto em sua essência enquanto cantora, como em sua intenção e inteiração no campo das artes. Nota-se uma ontologia múltipla, em que "várias Calcanhottos" se mostram em aparência, cujo fenômeno determinante pode ser o mesmo em sua essência. Mudam as aparências, mas as causas motivantes se mantêm, na observação e interação do corpo ao mundo. O corpo desta artista é um corpo em estado de incessante devir e este devir é inerente à estrutura da performance, em que nada é definitivo, tudo flui, se modifica, se transforma, se dissolve e se esvai.

Cada performance é única em seu instante, momento e ritmo. Mesmo que o artista esteja atuando num mesmo espetáculo durante uma longa temporada, nenhuma apresentação será exatamente igual à anterior, pois cada uma é movida por seu ritmo singular que se transforma conforme o momento e a emoção do artista. Um cantor pode repetir todas as noites o mesmo show sem modificar a sequência do repertório, cenário e músicos, mas não pode repetir com exatidão a emoção que conduziu a expressividade singular de cada instante. Uma performance marca identidade, modifica e redimensiona o tempo, conta histórias e permite que se jogue com condutas repetidas na medida em que o artista prepara, ensaia, apresenta e representa estas condutas. Ao mencionarmos a questão do ritmo único que move o instante de cada performance, estamos falando indissociavelmente do tempo. A arte interfere no ritmo corporal daquele que a constrói e daqueles que a recebem, principalmente quando se trata de uma criação que acontece em tempo-espaço real. Um espetáculo musical ao vivo, a dança e o teatro são exemplos de criações artísticas que requerem a presença do artista e do público para que aconteçam.

O corpo do artista é um espaço de discussão e confronto entre desejos e imposições, fluxos pessoais e coletivos, numa espécie de campo de batalha que negocia as crises de seu próprio tempo e seu contexto de criação e convivência. A arte não se elabora enquanto afirmação de um único artista, mas é o resultado de um estado dinâmico, amplo e complexo de relações. Ela sempre estará imbuída de uma dimensão política na medida em que operar politicamente pela articulação de seus discursos corporificados, afetivos e sensoriais. Por colocar em evidência um espaço de reflexão sobre seu próprio contexto, reelaborando paradigmas e recriando novos modos de organização e percepção, a arte em sua amplitude é capaz de continuamente se recriar numa ampla dimensão política.

O estilo, a forma ou o ritmo imposto pelo artista são a assinatura de sua vontade, a criação de um idioma particular, um projeto de impressões sensoriais que elaboram um cenário imaginário para a vontade do espectador. O artista, por meio de sua criação, constrói uma articulação de vontades através de um idioma que precisa ser partilhado, mas não necessariamente "entendido" de maneira racional. O espectador pode partilhar uma obra acionando sua sensibilidade, seus sentidos. A arte contemporânea sobretudo se encontra focada no âmbito das relações, na intersubjetividade, não apenas como 
tema, mas como ponto de partida e chegada. Cada obra de arte pode ser entendida como o resultado do desejo do artista em habitar um mundo comum, numa construção coletiva de sentido, partilhada entre ele e o público. Como afirma Deleuze, "desejar é construir um agenciamento, construir um conjunto, um conjunto de uma saia, de um raio de sol [...]" (DELEUZE: 1988/1989). Sob o olhar do teórico o desejo se fundamenta pelo construtivismo.

Dando continuidade ao pensamento Deleuziano, podemos afirmar que não há potência em arte que não passe pelo agenciamento do desejo. O criador não ambiciona apenas produzir arte, mas deseja "incomodar" o público produzindo sua arte num contexto, gerando impactos nos corpos daqueles que a recebem. Desejar é também delirar e "delira-se sobre o mundo inteiro, delira-se sobre a história, a geografia, as tribos, os desertos, os povos" (DELEUZE: 1988/1989).

O cantor, assim como o ator diante de um texto alheio, expande seu universo sensível para imprimir sua marca. A sua forma de entendimento da letra, as palavras que serão por ele cantadas estarão a serviço de sua própria percepção. O cantor, ao escolher uma música de um outro compositor para interpretar, utiliza seus próprios recursos vocais e sua criatividade para instaurar sua versão única. Calcanhotto exerce o dúbio ofício de intérprete de suas próprias composições e de canções alheias. Quando sua voz se coloca a serviço da interpretação de músicas de outros compositores, se torna ainda mais evidente sua assinatura.

A artista, ao eleger músicas de distintos compositores, deixa manifestar o seu modo de compreensão da canção na maneira como adapta sua voz ao entendimento dos versos e à cadência dos sons. Cada interpretação requer uma compreensão própria; a canção por si só aponta caminhos de leitura que a cantora deve buscar até encontrar sua forma ideal. Cada compositor traz o seu modo musical implícito em sua canção, seu estilo, que por si só o faz diferente de outro compositor. A relação entre intérprete e canção pode se efetuar num sentido pleno de apropriação por parte do cantor, que estabelece uma comunhão com a música, resultando num casamento perfeito entre som e voz. Conforme Zumthor define, duas leituras não podem ser vocalmente idênticas, nem, portanto, ser portadoras do mesmo sentido, mesmo que partam de igual tradição (ZUMTHOR: 1993). “A tradição, quando a voz é seu instrumento, é também, por natureza, o domínio da variante; daquilo que, em muitas obras, denominei movência dos textos" (ZUMTHOR,1993, p.144). Ele argumenta que a movência é uma criação contínua. A poesia vinha acompanhada de um canto em grande parte da Idade Média, nesse sentido poesia e música tinham em comum o fato de serem constantemente "rememoradas" e re-elaboradas pela performance. Essa reflexão que o crítico traz, com base num tempo decorrido, ainda pode ser aplicada aos dias atuais, a assinatura rasurante de Calcanhotto impressa em suas interpretações demonstra a sua habilidade criativa diante de textos poético-musicais em constante movência. Calcanhotto, no espetáculo registrado em VHS, deixa em evidência o forte diálogo que estabelece com o público: ela faz dos espectadores participantes ativos, na medida em que dão complementariedade a sua atuação. 
Vou aproveitar e dar uma dica para descontrair o ambiente, que é uma idéia simples e absolutamente genial que eu tive um dia desses. Fiquei pensando como ninguém pensou nisso antes, uma coisa tão básica, tão fácil. Fico pensando que na música popular brasileira muitos vão querer fazer como eu, e estou registrando a idéia para vocês. Sou capaz de ficar muito rica com isso. Vou dividir a platéia em dois, então quem gosta encha por favor a boca e cante com vontade, pois faz bem para a pele . E quem não gosta, cante com mais vontade ainda que espanta os males e fica tudo sob controle. Não sei gente, mas eu acho que vocês possuem potencial para muito mais, para se superarem, darem mais de si. Vamos por favor usar o poder da mente. Vou explicar uma coisa para vocês, isso aqui é uma troca, mas nós que somos todos irmãos, nós que todos votamos na mesma pessoa há tantos e tantos anos. Vamos usar o poder da mente, vamos dar as mãos, pois estou sentindo no ar uma energia. Uma coisa, um astral, ficaria horas aqui olhando essa coisa, uma coisa um pouco azulada talvez, talvez não seja azulada, talvez seja rosa. Um astral, uma coisa. Então se temos essa coisa, vamos todos botar essa coisa para fora, vamos cantar juntos. (HTTP://www.youtube.com/watch?v=_2MUDdy9)

De acordo com Zumthor, a performance, ato de comunicação que, como tal, refere-se a um momento tomado como presente, significa

a presença concreta de participantes implicados nesse ato de maneira imediata. Nesse sentido não é falso dizer que a performance existe fora da duração. Ela atualiza virtualidades mais ou menos numerosas, sentidas com maior ou menor clareza. Ela as faz "passar ao ato", fora de toda consideração pelo tempo. [...] A performance é então um momento de recepção: momento privilegiado, em que um enunciado é realmente recebido. (ZUMTHOR, 1993, p, 50)

Zumthor menciona a performance e sua ocorrência em tempo real, em que o artista, com seu ritmo, forma e estilo, impõe sua assinatura que o singulariza. $O$ performer partilha com o público seus conhecimentos e experiências, cujo objetivo é fazer com que o espectador compreenda primordialmente pelos sentidos. Como defende Susan Sontag, uma obra de arte necessita ser abarcada não unicamente como algo interpretado, mas também como tratamento do inexprimível. Nota-se, no espetáculo dirigido por Zelito Viana, a intenção de Calcanhotto em trabalhar sob as fronteiras do inexprimível, em que sua atitude provocativa visa deixar sob a plateia uma sensação de dúvida, inquietude, suspensão. A arte em muitos aspectos diz mais pelo não dito do que pelo escancaradamente explícito. Sontag define:

No sentido mais estrito, todos os conteúdos da consciência são inexprimíveis. Mesmo a mais simples sensação é, em sua totalidade, indescritível. Toda arte, portanto, precisa ser compreendida não apenas como algo interpretado, mas também como um certo tratamento do inexprimível. Na arte mais erudita,estamos sempre conscientes de coisas que não podem ser ditas (normas do "decoro"), da contradição entre expressão e a presença do inexprimível. Os artifícios estilísticos são também técnicas de suspensão. Os elementos mais poderosos de uma obra de arte, frequentemente, são seus silêncios. (SONTAG, 1987, p.48)

O silêncio do corpo é o lugar onde as forças impositivas se evidenciam e se calam simultaneamente, e pode-se vislumbrar, por alguns instantes, um pequeno espaço, livre e indefinido, no qual tudo pode vir a ser ou transformar-se. $\mathrm{O}$ mais instigante no momento da performance não é o instante em que o receptor consegue traduzi-la, captá- 
la integralmente, mas o instante exato de sua estranheza, quando a criação do artista consegue desprende-lo de sua fixação em realidades já codificadas e até saturadas.

Os processos de criação ocorrem no âmbito da intuição. As múltiplas opções e decisões que surgem no trabalho de um artista e delimitam a sua criação não se reduzem ao conhecimento consciente. Os mecanismos intuitivos tornam-se conscientes na medida em que são expressos, ou seja, na medida em que o criador lhes dá uma forma. A consciência por si só não é algo acabado ou definitivo, ela vai se compondo no exercício de si mesma, num processo dinâmico de constante renovação.

Nos processos de conscientização do indivíduo criador, a cultura exerce um papel fundamental, pois influencia seu senso perceptivo. Ela é importante no sentido de que orienta seus interesses e íntimas aspirações, sugerindo possíveis ou desejáveis formas de participação sociais, objetivos e ideais. A cultura orienta o ser sensível ao mesmo tempo que orienta o ser consciente. Nesse sentido a sensibilidade do indivíduo é aculturada e orienta o seu fazer e imaginar. Entre pequenos silêncios e fissuras, Calcanhotto dá margem à riqueza de suas interpretações, que visam continuamente a desestruturar o lugar comum. Em seu modo de cantar que impõe modalidades rasurantes, ela mexe com os pilares de estruturas já codificadas e insere sua marca própria. A maior parte das interpretações da artista, evidenciada no show dirigido por Zelito Viana, expõe uma intenção rasurante, em que ela propositalmente subverte o modo tradicional da interpretação. "Pierrô apaixonado" (Lamartine Babo e Noel Rosa), conhecida como marchinha de carnaval, recebe uma levada peculiar da cantora ao violão, que dá destaque a uma performance mais visceral em relação à dos compositores. A leveza da concepção sonora desta clássica marchinha é substituída por uma leitura mais agressiva, em que o toque das cordas do violão imprime uma sonoridade mais forte, bem projetada para fora, em consonância com a voz, que também contraria a docilidade da interpretação original. O diálogo interativo artista/plateia se realiza nesta canção na forma como Calcanhotto convida os participantes a cantarem junto com ela, compondo uma atuação coletiva.

A importância da relação corpo-voz do artista não se estabelece numa simbiose dissociada do universo exterior que o circunda. Há necessariamente a existência de um ser-corpo no mundo. Não há corpo absolutamente solitário, dissociado de influências externas. O corpo num ato performático é sempre uma via de mão dupla, receptor e veiculador de emoções e invenções. A criação do performer transforma-o num corpo vibrátil criador/receptor, pois ele precisa se tornar atento ao que dele emana e o que ele recebe e como nele ressoa. Trata-se de um jogo que estabelece suas relações entre o dentro e o fora com suas permeabilidades e limiares, continuamente margeados por fissuras.

Abordar o corpo em sua amplitude necessariamente nos impulsiona a refletir sobre as relações que ele trava com o universo exterior; suas vivências em relação ao espaço são determinantes na construção do senso de identidade. Conforme reflete a educadora Fayga Ostrower, o espaço consiste "tanto no meio como no modo" de nossas experiências vivas. Podemos dizer que o corpo, enquanto dimensão espacial da 
condição humana, é também nosso meio e modo de ser e estar no mundo. Conforme reflete Fayga Ostrower:

As formas de espaço constituem tanto o meio como o modo de nossa conscientização, ou seja, o espaço torna-se, simultaneamente, forma das experiências vividas e imagem de seus conteúdos [...] E do mesmo modo, quaisquer conteúdos afetivos que queremos expressar e comunicar aos outros são por nós traduzidos intuitivamente como imagens de espaço. Mesmo quando essa comunicação se dá a nível verbal. Ao dizermos, por exemplo, que algo nos toca de modo profundo ou apenas superficial, usamos intuitivamente imagens de espaço. Quando falamos das qualidades de um indivíduo (um ser in-divisível),como sendo aberto ao mundo ou fechado, como sendo expansivo ou introvertido, desligado, envolvente, atraente, repulsivo, distante, próximo, usamos sempre imagens de espaço. Não há outra maneira possível de conscientizar, formular e comunicar nossa experiência. (OSTROWER, s/d, p.86)

Como argumenta Fayga, todo o campo de apreensão e expressão de um indivíduo encontra-se intimamente ligado às relações que ele estabelece com o espaço. Este procede como um referencial analítico que agrega percepções afetivas e descobertas criativas. É por meio da associação aos referenciais espaciais que o criador se torna apto a fundamentar e comunicar sua experiência.A performance de um artista se realiza por meio do tipo de envolvimento que ele estabelece com o espaço, sua proximidade ou distanciamento corresponde ao nível de intensidade ao qual deseja alcançar. Uma apresentação de caráter intimista traz como perspectiva uma relação mais próxima entre criador e espectador, como se verifica no trabalho de Calcanhotto registrado em VHS.

A ironia que prepondera em algumas interpretações do show dirigido por Zelito Viana expõe os diálogos que a cantora estabelece com o espaço exterior, que se dá através de uma relação crítica e muitas vezes irônica com distintas alteridades. Em "Injuriado", ela canta e representa um alguém sem identidade definida, mas que adquire força através de sua performance repleta de inferências. Nesta música a artista concentra a maior parte de sua potência criativa nos movimentos faciais, boca, maxilares, queixo e olhos se esticam e contraem numa movimentação de cunho expressionista.

Embora Calcanhotto neste show se restrinja ao formato reduzido voz e violão, ela utiliza a proximidade com a plateia favorecida por esse caráter intimista para dar mais vigor ao seu desempenho cênico. A predominância de uma postura teatral evidenciada na performance desta artista irá sofrer nítidas transformações no decorrer de seus sucessivos trabalhos. A expressividade do seu canto, neste início de carreira, denota uma empostação diferente; a voz manifesta uma intensidade maior de volume e se projeta de maneira mais expansiva, com uma potência vibratória mais acentuada. Calcanhotto percorre linhas melódicas ascencionais que dão destaque à emissão de notas agudas, como se verifica em sua interpretação de Nunca (Lupicínio Rodrigues).

A expressividade do canto desta artista evoluirá cada vez mais numa direção oposta ao que se observa neste show. A voz, que, no início de carreira, se sobressai pela alternância de movimentos de aclives e declives, irá mudando sua modalidade vibratória no decorrer dos trabalhos seguintes. A considerável ênfase no desempenho 
performático, presente no show em VHS, que reproduz a atmosfera do primeiro disco, será substituída por um trabalho musical que incide num apuro técnico mais preciso. $\mathrm{O}$ foco mais direcionado para a questão teatral, explicitado no vídeo dirigido por Zelito, suplantava de certa maneira uma preocupação mais incisiva com as peculiaridades e minúcias do canto. Importava mais o impacto causado pelo todo, efetuado num desempenho teatral cuja atitude vale mais que o depuramento da voz. Quanto à afinação e equilíbrio entre texturas sonoras, Calcanhotto, no decorrer de sua carreira, vai apresentando um processo de destacável amadurecimento. Ousaríamos dizer que, no espetáculo da temporada de "Enguiço", a artista ainda mostrava certos traços de verve mais amadora, da qual ela vai se despindo ao longo de seu percurso musical. Somente a partir de seu terceiro disco, A fábrica do poema, ela define o padrão de emissão vocal que irá seguir durante todos os trabalhos sucessivos. Um canto cool, comedido, preciso. Observa-se no vídeo que há uma preocupação maior com a representação do que com a interpretação, ou seja, a cantora, neste caso, é muito mais uma atriz que canta do que uma cantora em essência. A intenção da artista se volta mais para a performance, cujo ato de cantar aparece mais a serviço de um enfoque representativo.

No início de carreira da artista, era predominante uma preocupação com o desempenho performático. Sua musicalidade encontrava-se a serviço de uma proposta que abrangia não exclusivamente as questões relacionadas ao papel do canto, mas também um projeto híbrido que incorporasse teatro e música. A voz demonstrava propositalmente um aspecto mais "sujo", que consistia justamente no resultado de um objetivo menos centralizado na emissão do canto e mais na performance cênica. Calcanhotto conectava-se mais com um universo "alternativo" que se manifestava por uma postura mais radical em termos de atitude. A finalidade era impactar o público, e esse efeito se fazia por meio muitas vezes de performances mais efusivas, até agressivas.

Em sua versão de Caminhoneiro (Roberto Carlos/Erasmo Carlos), Calcanhotto explora o lado lúdico e kitsch dos versos da canção e abusa do humor, através da forma como modula a voz. Sua interpretação dá primazia a um proposital excesso interpretativo que visa a deixar evidente o traço "over" da música. A levada rítmica do violão é pulsante em sintonia com a projeção da voz que se impõe expansiva e sem comedimentos.

Quando refletimos sobre os métodos de criação nesta artista, consideramos pertinente retomarmos as reflexões de Fayga Ostrower, que defende que o processo criativo incorpora um princípio dialético. Este consiste num processo contínuo que se regenera por si mesmo, em que o ampliar e o delimitar representam aspectos concomitantes, aspectos que se encontram em oposição e tensa unificação. A cada etapa, o delimitar participa do ampliar. Existe um fechamento, uma absorção de circunstâncias anteriores e, partindo-se do que anteriormente foi definido e delimitado, abre-se espaço para uma nova abertura. Cada decisão tomada pelo criador representa um ponto de partida, num processo de transformação que está sempre recriando o impulso que o criou. 
O potencial criador elabora-se nos múltiplos níveis do ser sensível-cultural conscientedo homem, e se faz presente nos múltiplos caminhos em que o homem procura captar e configurar as realidades da vida. Os caminhos podem cristalizar- se e as vivências podem integrar-se em formas de comunicação, em ordenações concluídas, mas a criatividade como potência se refaz sempre. A produtividade do homem, em vez de se esgotar, liberando-se, se amplia. (OSTROWER, 1999, p.27)

Como define Fayga, a criatividade implica uma força crescente que continuamente se reabastece e se refaz nos próprios processos através dos quais se realiza. O disco, por exemplo, é uma obra que pode esgotar-se, no sentido de que limitase a um enquadramento temporal e espacial, contudo o artista é um ser inconcluso, movido por inquietações, dúvidas e descobertas que o alçam sempre a um incessante fazer e desfazer.

Ao tentarmos analisar as imagens de Calcanhotto presentes no vídeo devemos levar em conta que cabe a nós sempre uma incompletude, a falta ocasionada pela tentativa de apreensão de um instante não inteiramente vivido, mas que é transposto em imagem virtual já mediatizado pelo olhar do editor e do diretor. As imagens, após sofrerem um processo de edição, são exibidas sob uma perspectiva seletiva filtrada pela intenção do diretor. Principalmente no vídeo dirigido por Zelito Viana constatamos essa fronteira entre espectador/palco x espectador/vídeo, pois o show não segue contínuo do início ao fim de sua execução, há no entremear das apresentações inserções de outras filmagens que fornecem ainda mais indícios do processo de edição pela qual o material original passou.

Neste artigo procuramos mostrar como a produção criativa da cantora e compositora Adriana Calcanhotto está diretamente vinculada ao seu desempenho performático. Sua performance vocal está intimamente relacionada ao desvelar de seus movimentos corporais, corpo e voz compõem um todo pleno de referencias e sentidos. Por meio da análise do vídeo produzido pelo diretor Zelito Viana procuramos demonstrar a integração entre corpo e voz em suas diversas matizes na criação da artista. 


\section{REFERÊNCIAS BIBLIOGRÁFICAS}

AGAMBEN, Giorgio. O que é o contemporâneo? e outros ensaios. Tradução:

Vinícius Nicastro Honesko. Chapecó:Argos, 2009.

AGRA, Lúcio. O corpo performático. Nova Fronteira: 2010.

ANDRADE, Carlos Drummond de. Reunião. Rio de Janeiro: José Olympio, 1978.

DELEUZE, Gilles; GUATTARI, Félix. O que é a filosofia? Tradução: Bento Prado Jr e Alberto Alonso Munõs. São Paulo: Ed 34,2005.

ELIOT, T.S. Ensaios. Tradução: Ivan Junqueira. São Paulo: Art Nova, 1989.

. Tradition and the individual talent. Tradução: Ivan Junqueira. London:

Faber, 1975.

OSTROWER, Fayga. Criatividade e processos de criação. Cidade: Editora, 1999.

SHUSTERMAN, Richard. Consciência corporal. São Paulo: Editora Vida e consciência, 2012.

SODRÉ, Muniz. O dono do corpo. Rio de Janeiro: Mauad, 1998.

SONTAG, Susan. Contra a interpretação. Porto Alegre: L\&PM, 1987

ZUMTHOR, Paul. A letra e a voz. Tradução: Amálio Pinheiro e Jerusa Pires Ferreira. São Paulo: Companhia das Letras, 1993.

. Performance, recepção, leitura. Tradução: Jerusa Pires Ferreira e Suely

Fenerich. Rio de Janeiro: Cosacnaify, s/d. 


\section{Discografia}

Senhas. CD. Rio de Janeiro: Sony Music, 1992.

- Enguiço. CD. Rio de Janeiro: Columbia,1990. 